SARS-CoV-2 ile Enfekte iken Doğum Yapan Kadınlarda Postpartum Depresyon Riski Artıyor mu? Türkiye'de Bir Pilot Çalışma

\title{
Does the Risk of Postpartum Depression Increase in Women Who Gave Birth While Infected With SARS-CoV-2? A Preliminary Study in Turkey
}

Mehmet Murat Ișıkalan, Kübra Memnune Gündoğan, Parisa Ebrahimzadeh Khiavi, Elifsena Canan Alp, Ali Acar Necmettin Erbakan Üniversitesi Meram Tıp Fakültesi, Kadın Hastalıkları ve Doğum Anabilimdalı Perinatoloji, Konya, Türkiye

\section{$\ddot{O} Z$}

GíRiș ve AMAÇ: Doğum sonrası depresyon, hem annenin hem de bebeğin hayatını tehdit eden önemli bir durumdur. Bu çalışmada, SARS-CoV-2 virüsü ile enfekte iken doğum yapan çok özel bir hasta grubunda doğum sonrası depresyon araştırılmışıtır.

YÖNTEM ve GEREÇLER: Bu çalışma Nisan 2020 ile Kasım 2020 arasında doğum yapan kadınlar arasında yürütüldü. Dışlama kriterlerinin ardından, doğum sırasında Sars-Cov-2 ile enfekte olan toplam 30 seçilmiş kadın değerlendirildi. Aynı dönemde doğum yapan ve enfeksiyon öyküsü olmayan 30 kadından oluşan kontrol grubu eşleştirildi. Kadınlar doğum sonrası dönemde demografik, obstetrik bulgular ve Edinburgh doğum sonrası depresyon ölçeği (EPDS), Beck Depresyon Envanteri (BDI) ve Beck Anksiyete Envanteri (BAI) ölçeğine göre karşılaştırıldı.

BULGULAR: Doğum sirasinda Sars-Cov-2 ile enfekte olan 30 kadın (vaka grubu) ve aynı dönemde doğum yapan 30 enfekte olmayan kadın (kontrol grubu) değerlendirildi. Gruplar, demografik özellikler ve obstetrik sonuçlar açısından homojen olarak dağılmıştı. Vaka grubunda EPDS puanları anlamlı olarak daha yüksekti (13.0'avs 6.0, $p=0.031)$. Vaka grubunda, $E P D S$ kesme değeri $\geq 13$ olan hasta sayısı anlamlı olarak daha yüksekti (\% 53,3'e karşı\% 13,3, p=0,001). Ayrica BDI ve BAI değerleri vaka grubunda daha yüksekti (sirasıyla $p<0.001$; 10.0' $a, p=0.002$ ).

TARTIŞMA ve SONUÇ: COVID-19 enfeksiyonu geçiriken doğum yapmak, pandemide depresyon ve anksiyete düzeylerinin yanı sıra postpartum depresyon olasılığını artırıyor görünmektedir. Bu özel hasta grubu için psikolojik destek uygun görülmektedir.

Anahtar Kelimeler: : Anksiyete, COVID-19, doğum sonrası depresyon, gebelik, pandemi

\begin{abstract}
INTRODUCTION: Postpartum depression is an important condition that threatens the life of both mother and infant. In this study, postpartum depression was investigated in a very special patient group who gave birth while infected with the SARS-CoV-2 virus.
\end{abstract}

METHODS: This study was conducted among women who gave birth between April 2020 and November 2020. After the exclusion criteria, a total of 30 eligible women infected with Sars-Cov-2 at the time of delivery were evaluated. A control group of thirty women who gave birth in the same period and had no history of infection was matched. The women were compared according to demographics, obstetric findings and the Edinburgh postpartum depression scale (EPDS), Beck Depression Inventory (BDI) and Beck Anxiety Inventory (BAI) scale in the postpartum period.

RESULTS: Thirty eligible women (case group) infected with Sars-Cov-2 at the time of delivery and 30 uninfected women who gave birth at the same time (control group) were compared. The groups were homogeneously distributed in terms of demographic characteristics and obstetric outcomes. EPDS scores were significantly higher in the case group (13.0 vs 6.0, $p=0.031$ ). In the case group, the number of patients with an EPDS cut-off value $\geq 13$ was significantly higher $(53.3 \%$ vs $13.3 \%, p=0.001)$. In addition, BDI and BAI values were higher in the case group ( $p<0.001, p=0.002$, respectively).

DISCUSSION AND CONCLUSION: Giving birth while suffering from COVID-19 appears to increase the risk of pandemic depression and anxiety levels, as well as the likelihood of postpartum depression. Psychological support is considered appropriate for this special patient group..

Keywords: anxiety, COVID-19, pandemic, postpartum depression, pregnancy

Iletişim / Correspondence:

Dr. Mehmet Murat Işılkalan

Necmettin Erbakan Üniversitesi Meram Tıp Fakültesi, Kadın Hastalıkları ve Doğum Anabilimdalı Perinatoloji, Konya, Türkiye

E-mail: muratisikalan@gmail.com

Başvuru Tarihi: 05.01.2021

Kabul Tarihi:10.02.2021 


\section{INTRODUCTION}

Coronavirus disease (COVID-19) is an infectious disea seaffecting the whole world and increasingly thre atening the world population (1). This disease was declared to bea global pandemic by the World Health Organization (WHO) in March 2020 (2).

Depression is the most common mental illness worldwide and a leading cause of maternal morbidity in the perinatal period (3). In low and middle-income countries, about one in four women has postpartum depression $(4,5)$. Practice guidelines issued by the US Preventive Services Task Force recommend screening for depression in all postpartum women (6).

Since the beginning of the COVID-19 pandemic process, postnatal depression rates have increased in pregnant women (7). In addition, there have been some studies showing that COVID-19 disease is directly related to psychiatric outcomes (8).Although many studies have been conducted on depression during the COVID-19 pandemic period, no research has yet been conducted on the increase in postpartum depression rates in women who gave birth while infected with the Sars-Cov-2 virus. This issue becomes even more important when the neuropsychiatric symptoms of COVID-19 are also considered (9).

The aim ofthis study was to investigate the levels of postpartum depression in this very special group of patients who gave birth while suffering from COVID-19.

\section{MATERIALS AND METHODS}

\section{Participants}

For this cross-sectional study, permission was requested from the Health Ministry of the Republic of Turkey (permit No. 2020-10-20T22-30-30). In addition, the study was approved by the University ethics committee (Decision no: 2020/2878). Participants were recruited from the Obstetric Department of Necmettin Erbakan University Meram Faculty of Medicine, Konya, Turkey. Informed consent was obtained from all of the patients participating in the study. All procedures involving human participants were conducted in accordance with the ethical standards of the institutional research committee and with the 1964 Helsinki declaration and its later amendments or comparable ethical standards. During the study, medical support was recommended to all women at increased risk of depression.

Thirty women with COVID-19 who gave birth between March 2020 and November 2020 were included in the study. Thirty women who had uncomplicated pregnancies andgave birth in the same period but had never had COVID-19 were matched as the control group. Up to 7 days before birth, women with a positive nucleic acid amplification test (NAAT) were considered to be COVID-19 infected.

This study included pregnant women whose NAAT test was positive until 7 days before deliveryand native language is Turkish.

Women who had had COVID-19 in any period of pregnancy but had a negative NAAT test 7 days before birth, women under the age of 18 , immigrant women, multiple pregnancies, a history of psychiatric diseases or depression, complicated pregnancies, chronic systemic diseases and women whose diagnosis of COVID-19 was not proven by a NAAT test were excluded from the study.

Obstetric and demographic information of the patients were obtained from the hospital's electronic medical records. Information such as age, education level, income level, duration of marriage was recorded. The patients were interviewed by the researchers 4 weeks after birth, and the surveyquestions were asked. Apart from demographic information such as education and income level, each woman was asked 44 questions for 3 different assessment tests.

Scales
The Edinburgh Postpartum Depression Scale
(EPDS)
Maternal depression assessment was evaluated
using the Edinburgh postnatal depression scale,
which is the most commonly used and
recommended screening method for postpartum
depression (10). The Turkish validation of this
study has been done before (11). This survey
consists of 10 questions and the questions are
scored between 0 and 3 . The lowest score can be 0
and the highest is 30 . Women with a total score of

\section{Scales}

\section{(EPDS)}

Maternal depression assessment was evaluated using the Edinburgh postnatal depression scale, which is the most commonly used and recommended screening method for postpartum depression (10). The Turkish validation of this study has been done before (11). This survey consists of 10 questions and the questions are and the highest is 30 . Women with a total score of 
13 or more were considered to be at high risk of postpartum depression.

\section{The Beck Depression Inventory (BDI)}

This surveyconsists of 21 questions defined in 1961 and scored between 0 and 3 (12). Turkish validation has been done previously (13).

\section{The Beck Anxiety Inventory (BAI)}

This questionnaire also consists of 21 questions scored between 0 and 3 (14). The Turkish validation of this study has been done before (15).The higher the total score, the higher the anxiety level.

\section{Statistical analysis}

The $\mathrm{G} *$ Power 3.1 statistical analysis program (Erdfelder, Foul \& Buchner, Düsseldorf, Germany) was used to calculate the power of the study. The $\alpha$ error probability, effect size and power of the study were $0.05,0.8$ and 0.9 , respectively. The required sample size for each group was 28 , and the required total sample size was 56.

All data collected for statistical analysis were analyzed using the Statistical Package for the Social Sciences, version 23, SPSS Inc., Chicago, IL (SPSS). Continuous and categorical variables were given as median, mean \pm standard deviation and categorical variables as $\mathrm{n}(\%)$. The normal distribution of the data was evaluated with the Kolmogorov-Smirnov test. Independent $\mathrm{T}$ test, ChiSquare test, Mann Whitney $U$ test and logistic regression analysis were used. The SPSS Random sample feature was used to match the control group.

\section{RESULTS}

Thirty pregnant women diagnosed with COVID19 and 30 matched control group patients were evaluated. All of the patients gave birth by cesarean section. The groups were homogeneously distributed in terms of demographic characteristics such as age, body mass index (BMI), duration of marriage and education level (Table 1). In this study, no positive results for COVID tests were found in any newborns.

Median EPDS scores were significantly higher in the case group ( 13.0 vs $6.0, \mathrm{p}=0.031$ ). The number of patients with EPDS cut-off value $\geq 13$ in the case group was also significantly higher $(53.3 \%$ vs $13.3 \%, \mathrm{p}=0.001$ ) (Figure 1). In addition, the median BDI and BAI values were higher in the case group (12.0 vs $6.0, \mathrm{p}<0.001 ; 10.0$ vs $4.0, \mathrm{p}=0.002$, respectively) (Table 2).

When confounder factors such as age, years ofeducation, income level, working status and the number of the children were adjusted, the adjusted OR of EPDS $\geq 13$ in the case group was calculated as 12.89 (Table 3 ).

\begin{tabular}{|c|c|c|c|}
\hline & $\begin{array}{l}\text { Case Group } \\
(\mathrm{n}=30)\end{array}$ & $\begin{array}{l}\text { Control Group } \\
(n=30)\end{array}$ & $P$ value \\
\hline Age (years) & $\begin{array}{l}28.5 \quad(24.0, \\
32.2)\end{array}$ & $28.0(24.7,32.2)$ & $0.717^{\mathrm{a}}$ \\
\hline $\begin{array}{l}\text { Number of } \\
\text { children }\end{array}$ & $2(2,3)$ & $2(2,3)$ & $0.217^{a}$ \\
\hline $\begin{array}{l}\text { Age at marriage } \\
\text { (year) }\end{array}$ & $\begin{array}{l}22.0 \quad(19.7, \\
25.0)\end{array}$ & $22.3(18.0,24.0)$ & $0.688^{a}$ \\
\hline $\begin{array}{l}\text { Duration of } \\
\text { marriage (years) }\end{array}$ & $5.0(2.7,10.0)$ & $5(4.0,8.2)$ & $0.537^{a}$ \\
\hline $\begin{array}{l}\text { Gestational age at } \\
\text { birth (weeks) }\end{array}$ & $\begin{array}{l}38.2 \quad(36.5, \\
39.4)\end{array}$ & $37.7(36.7,38.7)$ & $0.450^{a}$ \\
\hline BMI $\left(\mathrm{kg} / \mathrm{m}^{2}\right)$ & $25.6 \pm 3.3$ & $28.0 \pm 4.3$ & $0.084^{b}$ \\
\hline Nulliparous & $9(30.0)$ & $4(13.3)$ & $0.117^{\mathrm{a}}$ \\
\hline Education (years) & $\begin{array}{l}12.0 \quad(8.0, \\
12.0)\end{array}$ & $12.0(5.0,12.0)$ & $0.482^{a}$ \\
\hline Working & $3(10.0)$ & 5 (16.7) & $0.353^{c}$ \\
\hline \multicolumn{4}{|l|}{ Income level } \\
\hline Low & $7(23.3)$ & $14(46.7)$ & \multirow[t]{3}{*}{$0.118^{c}$} \\
\hline Middle & $22(73.3)$ & $16(53.3)$ & \\
\hline High & $1(3.3)$ & $0(0.0)$ & \\
\hline Birth weight (kg) & $\begin{array}{l}2890 \quad(2545, \\
3185)\end{array}$ & $\begin{array}{l}3180 \quad(2580, \\
3590)\end{array}$ & $0.053^{\mathrm{a}}$ \\
\hline \multicolumn{4}{|c|}{$\begin{array}{l}\text { BMI, body mass index; Data are presented as }{ }^{a} \text { median }(25 \%, 75 \% \\
\text { interquartile range), mean } \pm^{b} \text { standard deviation, or }{ }^{c} n(\%)\end{array}$} \\
\hline
\end{tabular}




\begin{tabular}{|c|c|c|c|}
\hline & $\begin{array}{l}\text { Case Group } \\
(\mathbf{n}=\mathbf{3 0})\end{array}$ & $\begin{array}{l}\text { Control } \\
\text { Group }(n=30)\end{array}$ & $P$ value \\
\hline EPDS & $13(4.7,13.2)$ & $6.0(3.0,7.0)$ & $\mathbf{0 . 0 3 1}^{\mathrm{a}}$ \\
\hline BDI & $\begin{array}{l}12.0(6.0, \\
17.0)\end{array}$ & $6.0(2.0,10.0)$ & $<0.001^{\mathrm{a}}$ \\
\hline BAI & $\begin{array}{l}10.0(6.7, \\
14.0)\end{array}$ & $4.0(2.0,8.5)$ & $0.002^{\mathrm{a}}$ \\
\hline $\mathrm{EPDS} \geq 13$ & $16(53.3)$ & $4(13.3)$ & $0.001^{b}$ \\
\hline \multicolumn{4}{|c|}{$\begin{array}{l}\text { EPDS: Edinburgh Postpartum Depression Scale; BDI: Beck } \\
\text { Depression Inventory; BAI: Beck Anxiety Inventory;Data are presented } \\
\text { as a median (\%25,\% } 75 \text { interquartile range) or b }{ }_{n} \text { (\%)Significant } p \\
\text { values are shown in bold font } \\
{ }^{a} p \text { value is obtained by the Mann Whitney U test } \\
{ }^{b} p \text { value is obtained by the Chi-Square test }\end{array}$} \\
\hline
\end{tabular}

Table 3. Odds ratio values of pregnant women who gave birth while infected with Sars-Cov-2 compared to the control group

\begin{tabular}{|lll|}
\hline & Crude OR (95\% CI) & Adjusted OR \\
\hline EPDS $\geq 13$ & $7.42(2.07-26.55)$ & $12.89(2.11-78.60)$ \\
& $\mathrm{p}=0.002$ & $\mathrm{p}=0.006$ \\
\hline $\begin{array}{l}\text { Adjusted for age, years of education, income level, } \text { working status, } \\
\text { number of children }\end{array}$ \\
\hline
\end{tabular}

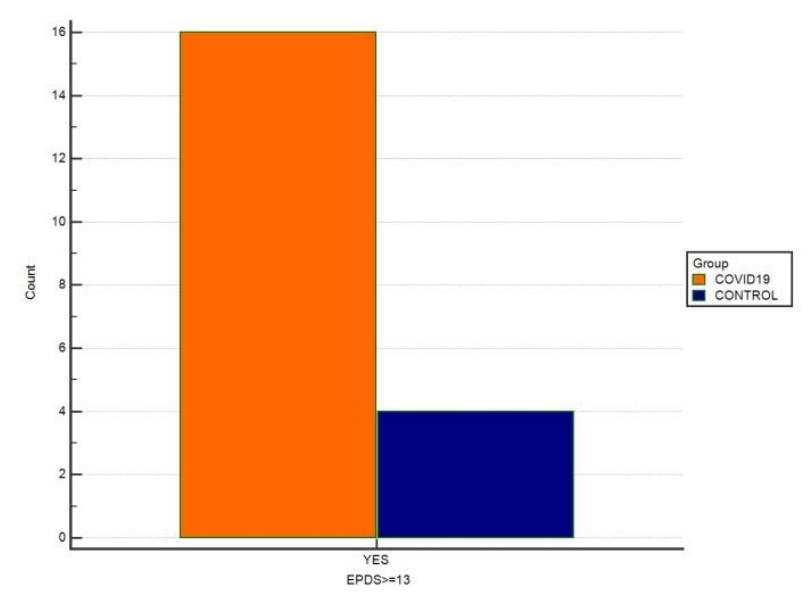

Figure 1. Comparison of the EPDS levels of thegroups

\section{DISCUSSION}

In this study, postpartum depression levels were investigated in women who gave birth while the COVID-19 pandemiccontinues. Postpartum depression is one of the most important issues threatening the life of both mother and baby. In the current study, it was observed that postpartum depression and anxiety levels were higher in pregnant women who gave birth while infected with Sar2-Cov 2.

In a study by Wu et al., it was stated that important life-threatening public health events such as the COVID-19 pandemic can increase the risk of mental illness (including thoughts of self-harm) among pregnant women (7).

Turkey's first COVID-19 case was announced on March 11, 2020. The first fatalcase due to this disease was announced on 15 March 2020. After this date, restrictions in social life and curfews have been implementedfrom time to time. Factors such as increased mortality and restriction of social life during the pandemic period are already expected to increase depressive symptoms. In a study conducted in Turkey, it was stated that the COVID-19 pandemic may increase depression and anxiety levels in pregnant women (16).In addition, studies have suggestedthat a lack of physical activity is associated with postpartum depression $(17,18)$.

Postnatal depression is known to vary according to ethnic groups (19). In a study conducted in Turkey before the onset of COVID-19 pandemic, it was found that the ratio of women whose EPDS score was 13 or above was $15.5 \%$. In the current study, the depression and anxiety levels in the group without COVID-19 disease were found to be similar to the aforementioned study (13.3\%). However, this rate was found to be much higher in women who gave birth while infected with SARSCoV-2 (53.3\%). It does not seem possible to explain this solely based on the limiting effects of the pandemic on social life. To explain the relationship between giving birth while infected with SARS-CoV-2 and postpartum depression, the complex neurological effects of this virus need to be explained more clearly.

In a recent study, neuropsychological and neurophysiological features of fatigue were investigated in patients with COVID-19. It has been emphasized that COVID-19-associated inflammation may lead to GABAergic impairment (9). In a study conducted on 402 patients, Mazza et al. showedthat COVID-19 can cause symptoms such as posttraumatic stress disorder, depression, anxiety and insomnia (8). With the available information, it is not possible to determine whether 
these are direct effects of the virus. More extensivestudies will clarify this issue.

The strengths of this study are that the survey was conducted directly by the researchers over the phone rather than using online methods. In addition, to the best of our knowledge, there is no other study conducted on postpartum depression in women who gave birthwhile infected with SARS-CoV-2. However, this study does have some limitations. The study was conducted at a single center.Moreover, the sample size is relatively small, and long-term results were not analyzed.

\section{CONCLUSION}

In conclusion, COVID 19 is itself known as a disease that has neurological components and can lead to depression. However, postpartum depression and anxiety levels were found to be significantly higher in women who had this disease at the time of birth. Psychological support is considered appropriate for this special patient group.

\section{Acknowledgments}

The authors would like to thank Dr. Anita L. Akkas (Middle East Technical University (ret), Ankara, Turkey) for contributing to the English editing.

\section{REFERENCES}

1. 1. Wang C, Horby PW, Hayden FG, Gao GF. A novel coronavirus outbreak of global health concern. The Lancet. 2020;395(10223):470-3.

2. Cucinotta D, Vanelli M. WHO declares COVID-19 a pandemic. Acta Bio Medica: Atenei Parmensis. 2020;91(1):157.

3. Organization WH. Depression: A global public health concern. Geneva, Switzerland: WHO. 2012.

4. Dadi AF, Miller ER, Mwanri L. Postnatal depression and its association with adverse infant health outcomes in low- and middle-income countries: a systematic review and meta-analysis. BMC Pregnancy and Childbirth. 2020;20(1):416.

5. Kahveci G, Kahveci B, Aslanhan H, Bucaktepe PGE. Evaluation of prevalence and risk factors for postpartum depression using the Edinburgh Postpartum Depression Scale: a crosssectional analytic study. Gynecology Obstetrics \& Reproductive Medicine. 2020:1,7.
6. O'Connor E, Rossom RC, Henninger M, Groom HC, Burda BU. Primary Care Screening for and Treatment of Depression in Pregnant and Postpartum Women: Evidence Report and Systematic Review for the US Preventive Services Task Force. JAMA. 2016;315(4):388-406.

7. Wu Y, Zhang C, Liu H, Duan C, Li C, Fan J, et al. Perinatal depressive and anxiety symptoms of pregnant women during the coronavirus disease 2019 outbreak in China. Am J Obstet Gynecol. 2020;223(2):240.e1-.e9.

8. Mazza MG, De Lorenzo R, Conte C, Poletti S, Vai B, Bollettini I, et al. Anxiety and depression in COVID-19 survivors: Role of inflammatory and clinical predictors. Brain, Behavior, and Immunity. 2020;89:594-600.

9. Ortelli P, Ferrazzoli D, Sebastianelli L, Engl M, Romanello R, Nardone $R$, et al. Neuropsychological and neurophysiological correlates of fatigue in post-acute patients with neurological manifestations of COVID-19: Insights into a challenging symptom. $J$ Neurol Sci. 2020;420:117271.

10. Cox JL, Holden JM, Sagovsky R. Detection of Postnatal Depression: Development of the 10item Edinburgh Postnatal Depression Scale. Br J Psychiatry. 2018;150(6):782-6.

11. Aydin N, Inandi T, Yigit A, Hodoglugil NN. Validation of the Turkish version of the Edinburgh Postnatal Depression Scale among women within their first postpartum year. Soc Psychiatry Psychiatr Epidemiol. 2004;39(6):483-6.

12. Beck AT, Ward CH, Mendelson M, Mock J, Erbaugh J. An inventory for measuring depression. Arch Gen Psychiatry. 1961;4(6):56171.

13. Tuğlu C, Türe $\mathrm{M}$, Dağdeviren $\mathrm{N}$, Aktürk Z. The reliability and validity analysis of the Turkish version of Beck Depression Inventory for primary care. Turkish Journal Of Family Practice. 2007;9(3):117-22.

14. Beck AT, Epstein N, Brown G, Steer RA. An inventory for measuring clinical anxiety: psychometric properties. J Consult Clin Psychol. 1988;56(6):893.

15. Ulusoy M, Sahin NH, Erkmen H. The Beck anxiety inventory: psychometric properties. J Cogn Psychother. 1998;12(2):163-72.

16. Durankuş F, Aksu E. Effects of the COVID-19 pandemic on anxiety and depressive symptoms in pregnant women: a preliminary study. 
The Journal of Maternal-Fetal \& Neonatal Medicine. 2020:1-7.

17. Strøm M, Mortensen EL, Halldorson TI, Østerdal ML, Olsen SF. Leisure-time physical activity in pregnancy and risk of postpartum depression: a prospective study in a large national birth cohort. The Journal of clinical psychiatry. 2009;70(12):1707-14.

18. Nakamura A, van der Waerden J, Melchior M, Bolze C, El-Khoury F, Pryor L. Physical activity during pregnancy and postpartum depression: Systematic review and meta-analysis. J Affect Disord. 2019;246:29-41.

19. Liu CH, Tronick E. Rates and predictors of postpartum depression by race and ethnicity: results from the 2004 to 2007 New York City PRAMS survey (Pregnancy Risk Assessment Monitoring System). Matern Child Health J. 2013;17(9):1599610. 